\title{
Exchange Rate Pass-Through into China's Import Prices: An Empirical Analysis Based on ARDL Model
}

\author{
Peipei Hong, Fangfang Zhang \\ College of Economics, Jinan University, Guangzhou, China \\ Email: hongpeip@126.com,1543262955@qq.com
}

Received 8 March 2016; accepted 11 April 2016; published 14 April 2016

Copyright $@ 2016$ by authors and Scientific Research Publishing Inc.

This work is licensed under the Creative Commons Attribution International License (CC BY).

http://creativecommons.org/licenses/by/4.0/

(c) (i) Open Access

\begin{abstract}
This study analyzes the exchange rate pass-through into China aggregate import prices and prices of eleven industries under the HS classification. Chinese monthly data from July 2005 to July 2015 are used. Bounds test finds that all industries have co-integration relationship, with the exception of footwear and headgear products (HS12) and transport equipment (HS17). We have researched the short- and long-run pass-through to China import prices with ARDL model and the estimated results are as follows: the degree of exchange rate pass-through to China's aggregate import prices is very high; both the short- and long-run coefficients for various industries are fairly different; the pass-through coefficient is high in industries of basic metals and metal products, chemical products, pulp and paper products, plastic and rubber products; the degree of pass-through is comparatively low in industries of textiles products, raw hides, leather and furs products, wood and wooden products and non-metallic mineral products; the pass-through into import prices for industries of machinery and equipment (HS16) is incomplete.
\end{abstract}

\section{Keywords}

Exchange Rate Pass-Through, Import Prices, ARDL Model

\section{Introduction}

Exchange rate pass-through (ERPT) refers to the elasticity of import and export prices and domestic price levels resulting from change in exchange rate. According to traditional international economic theories, the passthrough from exchange rate into price is complete while rapid. However, the reality of developed countries in 1970s shows that, the import and export prices did not fluctuate in line with the volatility in exchange rates as 
expected. Thus researchers began to focus on price ERPT effect. Studying exchange rate's impact on import prices can help evaluate the adjustments of exchange rate's expenditure-switching effect on international balance of payment, which has both theoretical and practical meanings for choosing a suitable exchange rate system.

The degree of ERPT depends on exporters' pricing strategy, that is, employing a strategy of producer-currency pricing (PCP) or local-currency pricing (LCP). The former denotes a situation that currency fluctuations completely translate into import prices while the latter corresponds to various prices exporters set in different markets. A great deal of foreign empirical evidences suggest that pass-through is incomplete, and researchers have explained it from various perspectives, both macro and micro.

Since RMB exchange rate reform in July, 2005, the ERPT into China prices has become a research hotspot. However, most existing studies merely focus the pass-through effect of aggregate price, but ignore its big divergences among various industries owing to foreign exporters' different pricing ability in China. Based on previous researches, this article employs auto regressive distributed lag (ARDL) model to analyze both the shortand long-run ERPT of RMB into aggregate import price and prices for various industries. This is to clarify domestic competitiveness of relevant industries and products which means a lot for China's industry structure adjustment and optimization.

The remainder of this paper is organized as follows: the following section briefly summarizes theoretical researches and empirical outcomes of ERPT at home and abroad. In Section 3, a theoretical model is built and analyzed, and thus we explain how to select variable indices related to our study. Section 4 is to empirically evaluate exchange rate volatility's impact on the aggregate import price and across product categories. The last section concludes.

\section{Literature Review}

It has been argued for a long time about fixed exchange rates and floating exchange rates in the international economies. Most researchers hold a view that floating exchange rates show more favour to one nation's adjustment capacity of its international balance of payment. Since the collapse of Bretton Woods system in 1970s, countries have adjusted their floating exchange rate regimes one after another, but the syndrome of trade imbalance among countries was not improved. This incomplete ERPT caused scholars' attention. Especially when yen's substantial devaluation failed to effectively improve the US trade deficit condition after the introduction of Hiroshima Agreement in 1980s, researchers began to explain the incomplete ERPT from both macro- and microeconomic aspects.

At the micro level, Krugman put forward the famous Pricing-To-Market (PTM) theory. He suggests that currently most markets in the world are in imperfect competition and are separated from each other. To maintain market shares, some industry producers may partly balance exchange rate fluctuations by changing profit margin or mark-up pricing, thus they develop different prices in different areas to maximize corporate profit [1]. Dornbusch considers that under the external volatility in exchange rates and wage stickiness, the extent of ERPT responds to product diversity and market share of import enterprises [2]. Knetter believes that the incomplete ERPT is the result of imperfect competition of markets and industrial organizations [3]. Goldberg and Knetter summarize researches related to ERPT [4].

From 1990s, researchers began to study ERPT from macro aspects. Obstfeld and Rogoff add factors such as price stickiness and incomplete market competition into dynamic general equilibrium model, and suggest that for prices in terms of import country's currency, the ERPT is complete when exporters employ PCP but is incomplete when employing LCP [5]. McCarthy's study shows that the extent of ERPT is associated with features of exchange rate volatility. When exchange rate is expected to continuously fluctuates, the ERPT into price will be more obvious [6]. Taylor argues that low inflation environment reduces the degree of ERPT. In an environment of low inflation, the devaluation of the importing country's currency weakens the persistent price rise, so exporters would maintain prices of importing goods and therefore pass-through declines [7].

A lot of empirical studies have proved that the incomplete ERPT is a common phenomenon, but its degree of import and export prices is considerably different in different countries and industries. Marston studies the ERPT effect of export prices of 17 HS four-digit manufacturing industries such as Japanese cars, tires, microwave ovens. He finds that pass-through coefficients are various across industries, and they do not have the same amplitude with the exchange rate fluctuations except the tires industry [8]. Campa and Goldberg employ the 
general linear regression model to study the short- and long-run ERPT into import prices for 5 industries of 25 nations. Their study show that most exporters are likely to adopt PCP pricing, and compared to food and industrial products, the degree of ERPT in energy and primary products is higher [9]. Parsley selects 21 SITC fivedigit products and the expected ERPT coefficient of import prices is between $0.8-0.95$ [10].

After the exchange rate reform in July, 2005 when RMB exchange rate volatility increases, researches of ERPT into China prices have been gradually deepened. However, a large number of studies are focused on export prices and domestic price level but merely study the ERPT issue of import prices and not have concrete or in-depth researches in specific industries. Chen L. F. and Liu H. J. apply VAR model to study exchange rate's impact on import prices and consumer prices over the period of Jan. 1990-June 2005, indicating that the degree of pass-through is very low [11]. Taken quarterly data from 2005-2007, Xu W. and Fu X.G. employ linear regression method to find a short-run coefficient of -0.26 , while the long-run coefficient is -0.29 . Meanwhile, by applying rolling regression method, they discover that the ERPT coefficient during this period first rose then declined [12]. Bi Yujiang obtains the long-run pass through of 0.96 based on co-integration techniques and discovers time lag of ERPT into import prices based on vector error correct model [13]. Wang J. B. and Li N. find that China's aggregate import price is sensitive to exchange rate fluctuations over the period of Jan. 2001-Mar. 2008 and the ERPT coefficient increases after 2005 [14].

At a disaggregated industry level, Wan X. L., Chen B. K. and Fu X. G. employs distributed-lag model to analyze ERPT into import prices for 10 industries and introduce tariff as a controlled variable. They find that industrial ERPT coefficients greatly vary and resource products have higher ERPT degrees in both the short- and long-run [15]. By introducing price lags and GMM two-stage Instrumental Variables Method, Cao W. and Shen Y. (2013) analyze relations between import prices and exchange rate fluctuations in 13 industries, delivering a conclusion different from Wan X. L.'s. They find that general import prices and in special equipment and transportation industries basically have no reaction to or even against exchange rate, and mineral commodities such as crude oil and ferrous metals have very low degree of pass-through [16].

To sum up, there are not many domestic researches about exchange rate volatility impact on China's import price, on both aggregate import prices and disaggregated perspective, and there is no consistent conclusion. Our study differs from previous researches in several respects: most studies use main import goods data to form the import prices indices, while the indices under the HS classification are relatively more reliable, which published by China's General Administration of Customs. This paper applies bounds test to determine long-run equilibrium relationship and uses ARDL-ECM model to study short-run dynamic relationship, avoiding both spurious regression and lose of long-run information owing to differential data. Furthermore, we take sample data after the year 2005 when RMB exchange rate reform took place, during which period RMB exchange rate fluctuation rage is large while mainly shows appreciation.

\section{Model and Data}

\subsection{Model}

To maximize profit, exporters usually develop discriminatory prices according to various exporting market environments. To study exchange rate volatility impact on importing goods prices in China, we shall first be aware of foreign exporters' pricing behavior. From the perspective of maximizing producer profit, this paper consults Bailliu and Bouakez's method to study foreign exporters' markups pricing strategy under imperfect competition [17]. Considering trade activities between a representative foreign exporter and domestic market which is assumed to be of imperfect competition, then the question of maximizing foreign exporters' profit should be:

$$
\operatorname{Max} \Pi_{i}=e P_{i}^{x} Q_{i}-C_{i}\left(Q_{i}, W_{i}\right)
$$

In Equation (1), $i$ represents different industries, $e$ denominates exchange rate (units of the exporter's currency per unit of the importer's currency), $P_{i}^{x}$ means foreign exporter's price of exporting goods (in terms of local currency), $Q_{i}$ refers to quantity demanded, $C_{i}$ denominates foreign production costs and $W_{i}$ represents input price. By adjusting $P_{i}^{x}$, foreign producers maximize their profit. After making first differences and Calculating, we get the exporting optimal pricing strategy of foreign producers:

$$
P_{i}^{x}=\frac{M C_{i}}{e} \times \frac{\eta_{i}}{\eta_{i}-1}=\frac{M C_{i}}{e} \times \mu_{i}
$$


In Equation (2), “ $M C_{i}$ ” represents producer’s marginal costs, “ $\mu_{i}$ ” represents markups over marginal costs and its value depends on price elasticity of demand $\left(\eta_{i}\right)$ in importing country. From Equation (2), we notice that, importing products prices in terms of local currency are decided by exchange rate, marginal costs and markups pricing. The latter two are affected by many factors. Marginal costs mainly depend on input prices such as raw material prices and wage level, and markups pricing on importing country's demand. Empirical researches usually simplify formula, select major controlled variables, take the logarithm of Equation (2) and indicate corresponding variables by lowercase letters, thus we obtain a basic equation for ERPT research:

$$
p_{t}=c+\alpha_{1} e_{t}+\alpha_{2} w_{t}+\alpha_{3} y_{t}+\varepsilon_{t}
$$

In Equation (3), $p_{t}$ represents import price, $e_{t}$ represents Nominal Effective Exchange Rate (NEER) and $w_{t}$ represents costs of producers. With respect to data availability, Producer Price Index (PPI) and Commodity Price Index (CPI) usually act as a proxy of marginal costs, $y_{t}$ describes domestic demand and often measured by GDP.

Since most macroeconomic variables are not stationary time series, if using differential data for regression analysis, long-run relationship between variables may be ignored. Therefore, many scholars employ Johansen's co-integration techniques to evaluate long-term relationship between import/export prices and exchange rate under the VAR framework. However, Johansen test usually requires all variables are integrated of the same order and needs to define lag numbers, choose various models and endogenous/exogenous variables, then obtaining different test results from various choices. Compared to E-G test and Johansen test, Pesaran put forward ARDL co-integration method and bounds tests which have significant advantages: first, as long as all variables are I(0) or I(1), ARDL model and bounds test can be used to distinguish and estimate long-run relationship between variables. Second, even there is an endogenous variable in control variables, the estimate is still effective and the result would not be affected. Third, results obtained from ARDL model are more reliable with small samples.

This paper adopts the ARDL $\left(p_{0}, p_{1}, p_{2}, p_{3}\right)$ model as follows:

$$
p_{t}=c+\sum_{k=1}^{p_{0}} \beta_{1 k} p_{t-k} \sum_{k=0}^{p_{1}} \beta_{2 k} e_{t-k}+\sum_{k=0}^{p_{2}} \beta_{3 k} w_{t-k}+\sum_{k=0}^{p_{3}} \beta_{4 k} y_{t-k}+\varepsilon_{t}
$$

\subsection{Data}

This paper selects data of the aggregate import price and prices of 11 manufacturing industries under Harmonized System (HS) classification from July 2005 to July 2015, researching ERPT to import prices. The 11 industries are: chemical products (HS06), plastic and rubber products (HS07), raw hides, leather and furs products (HS08), wood and wooden products (HS09), pulp and paper products (HS10), textiles products (HS11), footwear and headgear products (HS12), non-metallic mineral products (HS13), basic metals and metal products (HS15), machinery and equipment (HS16) and transport equipment (HS17). Descriptions of selected variables are as follows:

1) Industry Import Prices $(P)$

Industry import prices apply import price index under HS classification and are from China's External Trade Indices of the General Administration of Customs. Since the indices are exchanged for US dollars, we need to translate them into RMB according to the monthly average exchange rate at that period. With the help of chain index data of import prices in 2006, we transfer chain index into fixed base index.

2) Industrial Nominal Effective Exchange Rate (NEER)

Using a single NEER cannot well reflect industry differences owing to various import trades, so this paper forms NEERs for industries, making our empirical results more reliable. Refer to bilateral exchange rates between principal trade partner countries/regions and China for import goods based on HS classification, we weight bilateral trade volume to calculate NEERs in each industry (by Indirect Quotation). The calculation is as follows: get data of bilateral exchange rate that comes from International Monetary Fund (IMF), find annual trade volume of several principal trade partner countries/regions according to HS classification and their proportions from customs statistics report. The proportions are considered as weights of industrial NEERs and they are adjusted every year. By weighted geometric method, the formula is:

$$
N E E R_{t m}=100 \times E_{2006,1}^{2005,1} \times E_{2007,1}^{2006,1} \times \cdots \times E_{t, 1}^{t-1,1} \times E_{t, 1}^{t, m}
$$


In Equation (5), $N E E R_{t m}$ denotes $N E E R$ in m (month), $t$ (year), $E_{t, 1}^{t-1,1}$ denominates the weighted geometric mean of exchange rate in Jan. $t$ (year) compared to that in Jan. $t-1$ (year), $E_{t, 1}^{t, m}$ represents the weighted geometric mean of exchange rate in $m$ (month). $t$ (year) compared to that in Jan. $t$ (year).

$$
E_{t, 1}^{t, m}=\prod_{i}\left(\frac{E R_{t, m}^{i}}{E R_{t, 1}^{i}}\right)^{\omega_{i, t}}
$$

In Equation (6), $E R_{t, m}^{i}$ is exchange rate of country I (by Indirect Quotation) in m (month), $t$ (year), $E R_{t, 1}^{i}$ is exchange rate in Jan. $t$ (year), $\omega_{i, t}$ represents trade proportion of country $i$ in $t$ (year).

3) Exporters' Production Costs (W)

Owing to a lack of costs data such as raw material and wage, we draw on previous studies and adopt industry PPI as a proxy of exporter production costs. Find total and industry PPI data of principal trade partners, then transfer them into fixed base index taken 2005 as the base period, refer to the same proportion as when calculating NEERs, weight and calculate production costs. PPI data is from national official statistical offices.

4) Domestic Demand (Y)

Lacking monthly GDP data but it is highly correlated with monthly industrial value added, thus we use real monthly industrial value added as a proxy of domestic demand. To deal with real monthly industrial value added, we pick monthly nominal industrial value added data of 2005, reduce it with PPI index, then calculate real industrial value added in each period according to year-on-year growth data, and transfer data into fixed base index which considers Jan. 2005 as the base period. Data comes from Wind database.

Set Jan. 2005 as the base period and revise all the above data. Employ X12 method to make seasonal adjustments of the fixed base data. Since this paper studies ERPT which means exchange rate elasticity of import prices, we take logarithms of all variables, meanwhile it's helpful to eliminate heteroscedasticity. First we applicate stationary test to all variables, and then analyze variables' long-run relationship by bounds test, at last make an estimation with the ARDL model.

\section{Empirical Results and Analysis}

\subsection{Stationary Test}

To avoid spurious regression, we need to test time-series characteristics of all variables and determine whether variables are stationary with Augmented Dickey-Fuller (ADF) test. The null hypothesis is that the series has a unit root. The test results are: very few variables are stationary and most have unit roots, but these variables become stationary after first-differences, as shown in Table 1, all variables are I(0) or I(1), so bounds test approach could be used.

\subsection{Bounds Test}

To determine whether industry import prices have long-run co-integration relationship with exchange rate, production costs and domestic demand, an unrestricted Error Correction Model (UECM) is formed for bounds test:

$$
\begin{aligned}
\Delta p_{t}= & c+\sum_{k=1}^{p-1} \beta_{1 k} \Delta p_{t-k} \sum_{k=0}^{p-1} \beta_{2 k} \Delta e_{t-k}+\sum_{k=0}^{p-1} \beta_{3 k} \Delta w_{t-k}+\sum_{k=0}^{p-1} \beta_{4 k} \Delta y_{t-k} \\
& +\lambda_{0} p_{t-1}+\lambda_{1} e_{t-1}+\lambda_{2} w_{t-1}+\lambda_{3} y_{t-1}+\varepsilon_{t}
\end{aligned}
$$

The maximum lag number of UECM is taken 6, make OLS estimators for Equation (7) with lag number from 1 to 6, receiving Akaike Information Criterion (AIC) and Schwarz Bayesian Criterion (SBC) value, adjustment R2, Lagrange Multiplier (LM) test of first and forth order residual serial correlation (Table 2). Maximize AIC and SBC value of estimation model to select optimal lag length p. If the optimal lag length selected by AIC and SBC standards are not the same, then all lag numbers between them should be tested. The statistical software Microfit is used for estimation.

Add first order lag level variable to model of all lag numbers selected, determining whether there is long-run co-integration relationship between variables by the significant of F-Statistic. Null hypothesis is: $\lambda_{0}=\lambda_{1}=\lambda_{2}=\lambda_{3}=$ 0 , that is, no co-integration relationship exists between variables. Compare F-statistic with critical value table CI (iii) given by Pesaran Shin and Smith, where there are three independent variables. If the F-statistic is greater 
Table 1. Unit root tests results.

\begin{tabular}{|c|c|c|c|c|c|c|}
\hline Industry & $\mathrm{p}$ & e & $\mathrm{w}$ & $\Delta \mathrm{p}$ & $\Delta \mathrm{e}$ & $\Delta \mathrm{w}$ \\
\hline \multirow{2}{*}{ Total import } & $(c, 0,3)$ & $(\mathrm{c}, \mathrm{t}, 4)$ & $(\mathrm{c}, 0,1)$ & $(c, 0,2)$ & $(\mathrm{c}, 0,11)$ & $(c, 0,0)$ \\
\hline & $-2.738^{*}$ & $-3.185^{*}$ & -2.147 & $-4.455^{* * *}$ & $-4.862^{* * *}$ & $-5.463^{* * *}$ \\
\hline \multirow{2}{*}{$\begin{array}{l}\text { Chemical products } \\
\text { (HS06) }\end{array}$} & $(c, 0,4)$ & $(\mathrm{c}, \mathrm{t}, 4)$ & $(\mathrm{c}, 0,1)$ & $(\mathrm{c}, 0,7)$ & $(\mathrm{c}, 0,1)$ & $(\mathrm{c}, 0,2)$ \\
\hline & $-3.016^{* *}$ & $-3.163^{*}$ & -2.116 & $-4.704^{* * *}$ & $-4.494^{* * *}$ & $-5.313^{* * *}$ \\
\hline \multirow{2}{*}{ Plastic and rubber products (HS07) } & $(c, 0,7)$ & $(\mathrm{c}, \mathrm{t}, 4)$ & $(c, 0,12)$ & $(\mathrm{c}, 0,6)$ & $(c, 0,3)$ & $(\mathrm{c}, 0,11)$ \\
\hline & $-3.372^{* *}$ & -2.952 & -2.14 & $-4.390^{* * *}$ & $-3.970^{* * * *}$ & $-4.817^{* * *}$ \\
\hline \multirow{2}{*}{$\begin{array}{l}\text { Raw hides, leather and furs products } \\
\text { (HS08) }\end{array}$} & $(\mathrm{c}, 0,1)$ & $(\mathrm{c}, \mathrm{t}, 3)$ & $(\mathrm{c}, 0,2)$ & $(\mathrm{c}, 0,0)$ & $(\mathrm{c}, 0,1)$ & $(\mathrm{c}, 0,1)$ \\
\hline & -1.168 & $-3.658^{* *}$ & -0.109 & $-14.492^{* * *}$ & $-5.088^{* * * *}$ & $-5.482^{* * * *}$ \\
\hline \multirow{2}{*}{ Wood and wooden products (HS09) } & $(\mathrm{c}, 0,12)$ & $(\mathrm{c}, \mathrm{t}, 4)$ & $(\mathrm{c}, 0,0)$ & $(\mathrm{c}, 0,1)$ & $(\mathrm{c}, 0,0)$ & $(c, 0,0)$ \\
\hline & $-2.951^{* *}$ & -3.010 & -1.994 & $-2.913^{* *}$ & $-6.309^{* * * *}$ & $-11.527^{* * *}$ \\
\hline \multirow{2}{*}{ Pulp and paper products (HS10) } & $(\mathrm{c}, 0,5)$ & $(\mathrm{c}, \mathrm{t}, 4)$ & $(\mathrm{c}, 0,2)$ & $(\mathrm{c}, 0,1)$ & $(\mathrm{c}, 0,7)$ & $(\mathrm{c}, 0,1)$ \\
\hline & $-3.144^{* *}$ & -3.010 & -1.895 & $-4.677^{* * *}$ & $-4.718^{* * *}$ & $-3.991^{* * * *}$ \\
\hline \multirow{2}{*}{ Textiles products (HS11) } & $(c, 0,4)$ & $(\mathrm{c}, \mathrm{t}, 4)$ & $(\mathrm{c}, 0,11)$ & $(\mathrm{c}, 0,3)$ & $(\mathrm{c}, 0,3)$ & $(\mathrm{c}, 0,10)$ \\
\hline & -1.733 & -2.862 & -0.803 & $-4.340^{* * *}$ & $-3.877^{* * *}$ & $-2.958^{* *}$ \\
\hline \multirow{2}{*}{ Footwear and headgear products (HS12) } & $(c, 0,2)$ & $(\mathrm{c}, \mathrm{t}, 4)$ & $(\mathrm{c}, 0,3)$ & $(\mathrm{c}, 0,1)$ & $(\mathrm{c}, 0,4)$ & $(\mathrm{c}, 0,2)$ \\
\hline & -1.827 & -2.948 & 0.144 & $-12.250^{* * *}$ & $-5.914^{* * *}$ & $-5.147^{* * *}$ \\
\hline \multirow{2}{*}{ Non-metallic mineral products (HS13) } & $(c, 0,3)$ & $(\mathrm{c}, \mathrm{t}, 4)$ & $(\mathrm{c}, 0,4)$ & $(c, 0,2)$ & $(\mathrm{c}, 0,1)$ & $(c, 0,3)$ \\
\hline & -1.278 & -2.027 & -2.471 & $-11.926^{* * *}$ & $-7.948^{* * *}$ & $-3.766^{* * *}$ \\
\hline \multirow{2}{*}{ Basic metals and metal products (HS15) } & $(c, 0,5)$ & $(\mathrm{c}, \mathrm{t}, 4)$ & $(\mathrm{c}, 0,4)$ & $(c, 0,4)$ & $(\mathrm{c}, 0,1)$ & $(\mathrm{c}, 0,3)$ \\
\hline & -2.462 & -2.200 & -2.219 & $-3.623^{* * *}$ & $-4.336^{* * *}$ & $-4.112^{* * *}$ \\
\hline \multirow{2}{*}{ Machinery and equipment (HS16) } & $(c, 0,5)$ & $(\mathrm{c}, \mathrm{t}, 1)$ & $(\mathrm{c}, 0,5)$ & $(\mathrm{c}, 0,1)$ & $(\mathrm{c}, 0,1)$ & $(c, 0,4)$ \\
\hline & -0.549 & -2.042 & -2.195 & $-4.998^{* * * *}$ & $-4.428^{* * *}$ & $-3.310^{* *}$ \\
\hline \multirow{2}{*}{ Transport equipment (HS17) } & $(c, 0,4)$ & $(\mathrm{c}, \mathrm{t}, 1)$ & $(\mathrm{c}, 0,1)$ & $(\mathrm{c}, 0,4)$ & $(\mathrm{c}, 0,1)$ & $(c, 0,0)$ \\
\hline & -1.526 & -2.689 & 0.839 & $-7.210^{* * *}$ & $-5.169^{* * * *}$ & $-14.143^{* * *}$ \\
\hline
\end{tabular}

Note: Due to space limitation, test result of variable y is not shown but it is integrated of order one (I(1)). Three items in parentheses respectively denote whether the ADF test includes intercept ("t" means constant term exists while " 0 " means none), trend ("t" refers to time trend exists while " 0 " means none) and lag number " $\mathrm{k}$ ". The Lag lengths are determined by the AIC. ${ }^{* * *},{ }^{* * *}$ and ${ }^{*}$ denote significance at the $1 \%, 5 \%$ and $10 \%$ levels.

than the upper bound of critical value, then reject the null hypothesis; if lower than the bottom bound, then the null hypothesis of no co-integration is not rejected; if located between the upper bound and the bottom bound, then there is no certain conclusion [18].

According to Table 2, the F-statistic of footwear and headgear products (HS12) and transport equipment (HS17) industries are smaller than the upper bound of critical value at $10 \%$ significance level. Combine with stationary test results shown in Table 1, long-run co-integration relationships do not exist in variables in these two industries, but exist in other 9 categories and the total import.

For the industries where co-integration relationships exist, exclude lag numbers that have 1st and 4th order serial correlation at the same time and combine the adjustment $\mathrm{R}^{2}$ to select the optimal lag length. The optimal lag length are: 4 for the total import, 4 for HS06, 3 for HS07, 2 for HS08, 2 for HS09, 3 for HS10, 1 for HS11, 3 for HS13, 2 for HS15 and 2 for HS16.

\subsection{Estimation Results}

Having found the co-integration relationship between variables and the optimal lag length, we employ ARDL model in Equation (4) to estimate import price equation, select optimal $P_{0}, P_{1}, P_{2}$ and $P_{3}$ based on the AIC. 
Table 2. Selection criteria of model lag numbers and bounds test results.

\begin{tabular}{|c|c|c|c|c|c|c|c|}
\hline Industry & $\mathrm{p}$ & AIC & SBC & Adjusted $\mathrm{R}^{2}$ & $\chi^{2}(1)$ & $\chi^{2}(4)$ & F-statistic \\
\hline \multirow{2}{*}{ All } & 3 & 311.68 & 289.314 & 0.491 & 2.063 & $8.620^{*}$ & $7.815^{* * *}$ \\
\hline & 4 & 315.603 & 287.645 & 0.536 & 0.232 & 6.743 & $8.970^{* * * *}$ \\
\hline \multirow{3}{*}{ HS06 } & 2 & 285.674 & 268.899 & 0.45 & 0.028 & $14.889^{* * * *}$ & $6.369^{* *}$ \\
\hline & 3 & 288.667 & 266.3 & 0.491 & 0.001 & $7.886^{*}$ & $8.088^{* * * *}$ \\
\hline & 4 & 290.304 & 262.347 & 0.518 & 1.010 & 3.777 & $6.615^{* * * *}$ \\
\hline \multirow{2}{*}{ HS07 } & 2 & 273.148 & 256.373 & 0.496 & 1.532 & 6.826 & $15.628^{* * *}$ \\
\hline & 3 & 274.302 & 251.936 & 0.519 & $4.368^{* * *}$ & 6.152 & $11.091^{* * *}$ \\
\hline HS08 & 2 & 263.327 & 246.552 & 0.178 & 0.811 & 2.768 & $3.942^{*}$ \\
\hline HS09 & 2 & 200.656 & 183.881 & 0.263 & 0.561 & $9.204^{*}$ & $5.616^{* * *}$ \\
\hline HS10 & 3 & 297.323 & 274.956 & 0.505 & 0.001 & 1.725 & $4.309^{*}$ \\
\hline HS11 & 1 & 290.347 & 279.164 & 0.228 & 0.005 & 6.246 & $9.037^{* * *}$ \\
\hline \multirow{2}{*}{ HS12 } & 2 & 184.615 & 167.84 & 0.207 & $6.104^{* *}$ & 7.455 & $3.418^{\mathrm{b}}$ \\
\hline & 3 & 185.309 & 162.943 & 0.238 & $3.237^{*}$ & 4.875 & $2.017^{\mathrm{a}}$ \\
\hline \multirow{2}{*}{ HS13 } & 3 & 151.352 & 128.985 & 0.384 & 0.276 & $9.904^{* *}$ & $6.61^{* * *}$ \\
\hline & 4 & 153.122 & 125.164 & 0.418 & 0.157 & 7.497 & $3.605^{\mathrm{b}}$ \\
\hline \multirow[t]{2}{*}{ HS15 } & 2 & 257.508 & 240.733 & 0.389 & 2.060 & 5.174 & $5.507^{* *}$ \\
\hline & 2 & 221.107 & 209.924 & 0.425 & 0.062 & 1.903 & $8.043^{* * *}$ \\
\hline \multirow[t]{3}{*}{ HS16 } & 3 & 220.687 & 203.912 & 0.417 & 2.005 & 3.155 & $6.565^{* * * *}$ \\
\hline & 4 & 225.313 & 202.946 & 0.425 & 0.383 & 0.978 & $3.567^{\mathrm{b}}$ \\
\hline & 2 & 211.658 & 194.884 & 0.241 & 1.144 & 3.997 & $3.414^{\mathrm{b}}$ \\
\hline \multirow[t]{2}{*}{ HS17 } & 3 & 211.102 & 188.735 & 0.256 & 0.476 & 7.356 & $2.864^{\mathrm{b}}$ \\
\hline & 4 & 214.922 & 186.964 & 0.320 & 0.001 & 6.396 & $2.218^{\mathrm{a}}$ \\
\hline
\end{tabular}

Note: due to space limitation, Table 2 does not list the lag number when first and forth order serial correlation exists at the same time. ${ }^{* * *}$, ${ }^{* *}$ and ${ }^{*}$ refer to significance levels of $1 \%, 5 \%$ and $10 \%$. adenotes F-statistic is lower than the bottom bound of $10 \%$ significance level while; between the upper and bottom bounds. $\chi^{2}(1)$ and $\chi^{2}(4)$ denote LM test of 1st and 4th order residual serial correlation.

Equation (8) is a long-run coefficient model of ARDL estimates, and then we estimates short-run dynamic relationship between variables based on Error Correction Modal from ARDL (ARDL-ECM) in Equation (9):

$$
\begin{gathered}
p_{t}=c+\alpha_{1} e_{t}+\alpha_{2} w_{t}+\alpha_{3} y_{t}+E C M_{t} \\
\Delta p_{t}=c+\sum_{k=1}^{p_{0}-1} \beta_{1 k} \Delta p_{t-k} \sum_{k=0}^{p_{1}-1} \beta_{2 k} \Delta e_{t-k}+\sum_{k=0}^{p_{2}-1} \beta_{3 k} \Delta w_{t-k}+\sum_{k=0}^{p_{3}-1} \beta_{4 k} \Delta y_{t-k}+\delta E C M_{t-1}+\varepsilon_{t}
\end{gathered}
$$

Table 3 lists long-run equilibrium coefficients of total import and industries. As can be seen, industries NEERs (e) all have negative estimated values and are significant, meaning RMB appreciation largely lowers import product prices of all industries. Except commodities in category 16, exporter production costs obviously have positive effect on industry import prices. As commodities of category 16, the estimated coefficient of exporter production costs is negative but fails to pass the significant test at the $10 \%$ statistical level, which suggests that production costs have little impact on import prices of machinery and equipment industry (HS16), foreign exporters have strong bargaining power when exporting these products to China. There is a positive correlation between most industry import prices and China industry value added, with a small coefficient, illustrating that the increase of domestic demand would drive import prices up.

Table 4 shows the ARDL-ECM results in which estimated coefficients of most variables are significant. Error correction terms of ECM $(-1)$ for all industries are significantly negative. The sizes of error correction coefficients indicate various degrees of correction to long-run equilibrium state after import prices shocks. ECM 
Table 3. Long-run coefficient estimations using ARDL model.

\begin{tabular}{ccccc}
\hline Equation & $\mathrm{e}$ & $\mathrm{w}$ & $\mathrm{y}$ & $\mathrm{c}$ \\
\hline Total $(3,1,3,0)$ & $-1.238^{* * *}(-6.813)$ & $0.778^{* *}(2.367)$ & $0.244^{* * *}(3.399)$ & $5.582^{* * *}(3.022)$ \\
HS06 $(2,3,2,0)$ & $-1.110^{* * *}(-8.372)$ & $0.914^{* * *}(5.698)$ & $0.139^{* * *}(2.702)$ & $4.886^{* * *}(5.313)$ \\
HS07 $(2,0,2,0)$ & $-0.978^{* * *}(-5.570)$ & $1.774^{* * *}(4.343)$ & $0.311^{* * *}(4.791)$ & $9.481^{* * *}(5.318)$ \\
HS08 $(2,0,0,0)$ & $-0.661^{*}(-1.939)$ & $1.607^{* * *}(4.183)$ & $0.174(0.914)$ & $4.230^{* *}(1.998)$ \\
HS09 $(2,0,0,0)$ & $-0.583^{* * *}(-2.047)$ & $0.267^{*}(1.805)$ & $0.210^{* * *}(2.244)$ & $5.147^{* * *}(3.838)$ \\
HS10 $(3,1,3,0)$ & $-1.791^{* * *}(-6.230)$ & $1.330^{* * *}(2.105)$ & $0.199(1.489)$ & $5.821^{* * *}\left(1.93^{*}\right)$ \\
HS11 $(1,0,0,1)$ & $-0.523^{* * *}(-6.781)$ & $2.082^{* * *}(9.307)$ & $-0.151^{* * *}(-2.862)$ & $-1.839^{* *}(-2.049)$ \\
HS13 $(1,0,0,0)$ & $-0.648^{* * * *}(-3.102)$ & $0.629^{* * *}(1.991)$ & $0.030(0.580)$ & $4.620^{* * *}(2.201)$ \\
HS15 $(2,2,2,0)$ & $-1.438^{* * *}(-6.824)$ & $0.531(1.215)$ & $0.234^{* * *}(2.684)$ & $7.771^{* * *}(3.784)$ \\
HS16 $(2,0,0,0)$ & $-0.403^{* * *}(-4.013)$ & $-0.528(-1.225)$ & $-0.147^{* * *}(-4.1792)$ & $9.546^{* * *}(5.301)$ \\
\hline
\end{tabular}

Note: $t$ statistics are given in parentheses. ${ }^{* * * * *},{ }^{* *}{ }^{*}{ }^{*}$ denote significance levels of $1 \%, 5 \%$ and $10 \%$.

Table 4. Estimated short-run coefficient of ARDL-ECM.

\begin{tabular}{|c|c|c|c|c|c|c|c|c|c|c|}
\hline Variable & $\begin{array}{c}\text { Total } \\
(3,1,3,0)\end{array}$ & $\begin{array}{c}\text { HS06 } \\
(2,3,2,0)\end{array}$ & $\begin{array}{c}\text { HS07 } \\
(2,0,2,0)\end{array}$ & $\begin{array}{c}\text { HS08 } \\
(2,0,0,0)\end{array}$ & $\begin{array}{c}\text { HS09 } \\
(2,0,0,0)\end{array}$ & $\begin{array}{c}\text { HS10 } \\
(3,1,3,0)\end{array}$ & $\begin{array}{c}\text { HS11 } \\
(1,0,0,1)\end{array}$ & $\begin{array}{c}\text { HS13 } \\
(1,0,0,0)\end{array}$ & $\begin{array}{c}\text { HS15 } \\
(2,2,2,0)\end{array}$ & $\begin{array}{c}\text { HS16 } \\
(2,0,0,0)\end{array}$ \\
\hline$\Delta e_{t}$ & $\begin{array}{c}-0.163^{* * *} \\
(-1.020)\end{array}$ & $\begin{array}{c}0.150 \\
(0.818)\end{array}$ & $\begin{array}{l}-0.376^{* * *} \\
(-5.908)\end{array}$ & $\begin{array}{l}-0.180^{* *} \\
(-2.221)\end{array}$ & $\begin{array}{c}-0.2362^{* *} \\
(-2.277)\end{array}$ & $\begin{array}{c}0.331 \\
(1.430)\end{array}$ & $\begin{array}{c}-0.278^{* * *} \\
(-5.179)\end{array}$ & $\begin{array}{l}-0.440^{* * *} \\
(-2.912)\end{array}$ & $\begin{array}{c}-0.166 \\
(-0.792)\end{array}$ & $\begin{array}{c}-0.287^{* * *} \\
(-3.434)\end{array}$ \\
\hline$\Delta e_{t-1}$ & & $\begin{array}{c}-0.330 \\
(-1.571)\end{array}$ & & & & & & & $\begin{array}{l}-0.488^{* *} \\
(-2.063)\end{array}$ & \\
\hline$\Delta e_{t-2}$ & & $\begin{array}{l}0.750^{* * *} \\
(3.557)\end{array}$ & & & & & & & & \\
\hline$\Delta w_{t}$ & $\begin{array}{l}0.835^{* *} \\
(2.044)\end{array}$ & $\begin{array}{c}0.478 \\
(1.625)\end{array}$ & $\begin{array}{l}2.363^{* * *} \\
(3.736)\end{array}$ & $\begin{array}{l}0.290^{* *} \\
(2.535)\end{array}$ & $\begin{array}{c}0.108^{*} \\
(1.625)\end{array}$ & $\begin{array}{c}2.0628^{* *} \\
(2.334)\end{array}$ & $\begin{array}{c}1.1096^{* * *} \\
(5.297)\end{array}$ & $\begin{array}{c}0.427^{*} \\
(1.897)\end{array}$ & $\begin{array}{l}0.5499 \\
(0.755)\end{array}$ & $\begin{array}{c}-0.376 \\
(-1.190)\end{array}$ \\
\hline$\Delta w_{t-1}$ & $\begin{array}{c}0.703 \\
(-1.589)\end{array}$ & $\begin{array}{l}0.959^{* * *} \\
(3.202)\end{array}$ & $\begin{array}{l}3.626^{* * *} \\
(5.293)\end{array}$ & & & $\begin{array}{l}1.864^{* *} \\
(2.092)\end{array}$ & & & $\begin{array}{l}2.544^{* * *} \\
(3.561)\end{array}$ & \\
\hline$\Delta w_{t-2}$ & $\begin{array}{l}1.314^{* * * *} \\
(3.352)\end{array}$ & & & & & $\begin{array}{c}1.499^{*} \\
(1.703)\end{array}$ & & & & \\
\hline$\Delta y_{t}$ & $\begin{array}{l}0.091^{* * *} \\
(4.060)\end{array}$ & $\begin{array}{l}0.064^{* * *} \\
(2.649)\end{array}$ & $\begin{array}{l}0.108^{* * *} \\
(5.570)\end{array}$ & $\begin{array}{c}0.031 \\
(1.048)\end{array}$ & $\begin{array}{l}0.085^{* *} \\
(2.336)\end{array}$ & $\begin{array}{c}0.046 \\
(1.643)\end{array}$ & $\begin{array}{c}0.037^{*} \\
(1.924)\end{array}$ & $\begin{array}{c}0.021 \\
(0.577)\end{array}$ & $\begin{array}{l}0.062^{* * *} \\
(2.842)\end{array}$ & $\begin{array}{l}-0.105^{* * *} \\
(-3.384)\end{array}$ \\
\hline $\begin{array}{c}\text { ECM } \\
(-1)\end{array}$ & $\begin{array}{l}-0.372^{* * * *} \\
(-5.653)\end{array}$ & $\begin{array}{l}-0.464^{* * *} \\
(-6.069)\end{array}$ & $\begin{array}{l}-0.347^{* * * *} \\
(-8.096)\end{array}$ & $\begin{array}{l}-0.181^{* * * *} \\
(-3.692)\end{array}$ & $\begin{array}{l}-0.405^{* * *} \\
(-4.758)\end{array}$ & $\begin{array}{c}-0.233^{* * *} \\
(-6.401)\end{array}$ & $\begin{array}{l}-0.533^{* * *} \\
(-6.749)\end{array}$ & $\begin{array}{l}-0.678^{* * *} \\
(-7.451)\end{array}$ & $\begin{array}{l}-0.266^{* * *} \\
(-4.297)\end{array}$ & $\begin{array}{c}-0.714^{* * *} \\
(-5.814)\end{array}$ \\
\hline $\begin{array}{c}\text { Adjust } \\
\mathrm{R}^{2}\end{array}$ & 0.495 & 0.508 & 0.551 & 0.209 & 0.287 & 0.457 & 0.287 & 0.312 & 0.391 & 0.444 \\
\hline F-stat & $\begin{array}{c}15.9443 \\
{[0.000]}\end{array}$ & $\begin{array}{c}16.739 \\
{[0.000]}\end{array}$ & $\begin{array}{c}24.571 \\
{[0.000]}\end{array}$ & $\begin{array}{c}7.346 \\
{[0.000]}\end{array}$ & $\begin{array}{c}10.680 \\
{[0.000]}\end{array}$ & $\begin{array}{c}13.868 \\
{[0.000]}\end{array}$ & $\begin{array}{c}13.314 \\
{[0.000]}\end{array}$ & $\begin{array}{c}13.948 \\
{[0.000]}\end{array}$ & $\begin{array}{c}12.282 \\
{[0.000]}\end{array}$ & $\begin{array}{l}20.150 \\
{[0.000]}\end{array}$ \\
\hline DW & 2.098 & 2.016 & 1.883 & 2.041 & 2.034 & 1.954 & 2.004 & 2.079 & 2.023 & 1.993 \\
\hline CUSUM & Stationary & Stationary & Stationary & Stationary & Stationary & Stationary & Stationary & Stationary & $\begin{array}{l}\text { Not very } \\
\text { stationary }\end{array}$ & Stationary \\
\hline $\begin{array}{c}\text { CUSUM } \\
\text { SQ }\end{array}$ & Stationary & Stationary & Stationary & Stationary & $\begin{array}{l}\text { Not very } \\
\text { stationary }\end{array}$ & Stationary & Stationary & Stationary & $\begin{array}{l}\text { Not very } \\
\text { stationary }\end{array}$ & $\begin{array}{l}\text { Not very } \\
\text { stationary }\end{array}$ \\
\hline
\end{tabular}

Note: $\mathrm{t}$ statistics are given in parentheses, the figures in square brackets are P values. Due to space limitation, this table does not show the results of constant terms and autoregressive term. ${ }^{* * *},{ }^{* *}$ and ${ }^{*}$ denote statistical significance at the $1 \%, 5 \%$ and $10 \%$ level.

coefficients of all industries are reasonable. With regard to the situation that estimated coefficients may evolve over time, this paper employs two approaches (CUSUM Test and CUSUM-square Test) to examine stability of 
models' estimated coefficients. Results show that most industries are stationary at the 5\% significance level in both tests, but several could only pass one test and are not very stationary in the other. Overall, models are stable and estimated results are efficient.

After reviewing the value of ERPT coefficients, we have the following findings:

First, the ERPT coefficient of China's aggregate import price is quite high. Estimated results of ARDL model demonstrate that the long-run ERPT coefficient of aggregate import price is $-1.238,1 \%$ increase of RMB efficient exchange rate would lead to a $1.238 \%$ drop of import prices in RMB. Wald test indicates that the null hypothesis of complete pass through (coefficient is -1) cannot be rejected. The short-run exchange rate elastic of import prices is -0.163 and the short-run estimated coefficient is very small while not statistically significant, denoting time lag of ERPT into import price. As a developing country, China's ERPT effect of import price is larger than that in developed countries. The reason may be China's import goods are mainly priced in foreign currencies, so when exporters employ PCP strategy then the exchange rate volatility will completely pass into RMB pricing.

Second, ERPT coefficient has large differences in various industries, both in the short- and long-run. The absolute value of long-run ERPT coefficient has a lower bound of 0.403 and an upper bound of 1.791. By and large, the industry long-run exchange rate elasticity of import prices is very high. In short term, industry import prices have small ERPT coefficients and the coefficient even becomes positive when dealing with chemical and paper industries.

Third, the degree of ERPT is very significant in industries of basic metals and metal products (HS15), chemical products (HS06), pulp and paper products (HS10) and plastic and rubber products (HS07). China has no competitive advantage in these industries thus has no pricing power in international market, so exporters may maintain commodity prices in terms of their own currencies when facing exchange rate fluctuation of RMB. China has become a large producer of basic metals and metal products but is highly dependent on importing non-ferrous metal such as copper, aluminum and nickel, and iron and steel production mainly focus on lowto-mid end products while high-end ones rely much on import. As a technology-intensive industry, China's chemical products lag far behind from developed countries with obvious competitive disadvantages. Considering import product structure of paper, plastic and rubber industries, we notice that raw materials such as pulp and rubber have too large proportions. Compared to industrial products, prices of primary products are often decided by international market, affected much by costs and settled in US dollars, leading high ERPT effect.

Fourth, the degree of ERPT is relatively low in industries of textiles products (HS11), raw hides, leather and furs products (HS08), wood and wooden products (HS09) and non-metallic mineral products (HS13), which indicates that exporters will adjust make-up when selling these products. But as China has obvious competitive advantages in these labor-intense industries, exporters solely add small costs plus when RMB appreciates, so import prices largely fluctuate.

Fifth, the pass-through into China import prices for industries of machinery and equipment (HS16) are incomplete with a coefficient of -0.403 , and it may be because foreign exporters in this industry employ LCP strategy. Since the 21st century, China's machinery and equipment have a rapid export growth, greatly strengthening its competitive advantages. But in such an industry with intense capital and technology, most of China's products are of low tech while high-end machinery and equipment still rely on importing. For this reason, foreign enterprises merely adjust mark-up price for more profit instead of lowering product prices as the degree of RMB appreciation, leading to incomplete ERRT.

\section{Conclusions}

Based on import prices and exchange rate data from July 2005 to July 2015, this paper employs bounds test to evaluate long-run equilibrium relationship between the aggregate and industries import prices, industry NEERs, exporter production costs and China's monthly industrial value added, finding that all industries have co-integration relationship, with the exception of footwear and headgear products (HS12) and transport equipment (HS17). We have researched the short- and long-run ERPT into China's import prices with ARDL model and the estimated results are as follows: the degree of exchange rate pass-through to China's aggregate import prices is very high; both the short- and long-run pass-through coefficients for various industries are fairly different; the pass-through coefficient is high in industries of basic metals and metal products, chemical products, pulp and paper products, plastic and rubber products; the degree of ERPT is comparatively low in industries of textiles 
products, raw hides, leather and furs products, wood and wooden products and non-metallic mineral products; the pass-through into import prices for industries of machinery and equipment (HS16) is incomplete.

Our research illustrates that in the long run, ERPT into China's aggregate import prices has a high degree. RMB appreciation would lower import prices, enhance local residents' purchasing power, but whether it could improve imports and adjust international trade balance still needs further researches. To avoid adverse effects, China should upgrade industrial structure and eliminate outdated production capacity, enhancing technology and competitive strength for strengthened pricing power on the basis of giving full play to the labor and resources advantages.

\section{References}

[1] Krugman, P. (1987) Pricing to Market When the Exchange Rate Changes. NBER Working Paper, No. 192.

[2] Dornbusch, R. (1987) Exchange Rates and Rrices. American Economic Review, 77, 93-106.

[3] Knetter, M. (1989) Price Discrimination by U.S. and German Exporters. American Economic Review, 79, $198-210$.

[4] Goldberg, P.K. and Knetter, M.M. (1997) Goods Prices and Exchange Rates: What Have We Learned? Journal of Economic Literature, 35, 1243-1272.

[5] Obstfeld, M. and Rogoff, K. (1995) Exchange Rate Dynamics REDUX. Journal of Political Economy, 103, 624-660. http://dx.doi.org/10.1086/261997

[6] McCarthy, J.P. (2000) Pass-Through of Exchange Rates and Import Prices to Domestic Inflation in Some Industrialized Economies. Federal Reserve Bank of New York Working Paper, No. 111. http://dx.doi.org/10.2139/ssrn.249576

[7] Taylor, J.B. (2000) Low Inflation, Pass-Through, and the Pricing Power of Firms. European Economic Review, 44, 1389-1408. http://dx.doi.org/10.1016/S0014-2921(00)00037-4

[8] Marston, R. (1990) Pricing to Market in Japanese Manufacturing. Journal of International Economics, 29, 217-236. http://dx.doi.org/10.1016/0022-1996(90)90031-G

[9] Campa, J.M. and Goldberg, L.S. (2002) Exchange Rate Pass-Through into Import Prices: A Macro or Micro Phenomenon? Federal Reserve Bank of New York, No. 149.

[10] Parsley, D. (2003) Exchange Rate Pass-Through in a Small Open Economy: Panel Evidence from Hong Kong. International Journal of Finance and Economics, 8, 1-9. http://dx.doi.org/10.1002/ijfe.202

[11] Chen, L.F. and Liu, H.J. (2007) Exchange Rate Pass-Through into Prices of RMB: An Empirical Research Based on VAR Model. Journal of Financial Research, No. 4, 1-13.

[12] Xu, W. and Fu, X.G. (2008) A Research of RMB's NEER Pass-Through into Import Prices. Journal of Financial Research, No. 9, 77-90.

[13] Bi, Y.J. (2008) Exchange Pass-Through into China Import Prices: An Empirical Research Based on VECM. The Journal of Quantitative \& Technical Economics, No. 8, 70-81.

[14] Wang, J.B. and Li, N. (2007) An Empirical Analysis of Exchange Rate Pass-Through Effect in China. Economic Research Journal, No. 12, 106-117.

[15] Cao, W. and Shen, Y. (2013) Exchange Rate Pass-Through of RMB, Industry Import Prices and Inflation between 1996 and 2011. Journal of Financial Research, No. 10, 68-80.

[16] Wan, X.L., Chen, B.K. and Fu, XG. (2011) Exchange Rate Pass-Through on China's Import Prices and Foreign Exporters' Pricing Strategy: Evidence based on the Industry-Level Data. Studies of International Finance, No. 4, 18-29.

[17] Bailliu, J. and Bouakez, H. (2004) Exchange Rate Pass-Through in Industrialized Countries. Bank of Canada Review, Spring, 19-28.

[18] Pesaran, M.H., Shin, Y. and Smith, R. (2001) Bounds Testing Approaches to the Analysis of Level Relationships. Journal of Applied Econometrics, 16, 289-326. http://dx.doi.org/10.1002/jae.616 